\title{
Flavonoid from Stem Bark of Aquilaria microcarpa
}

\author{
A. N. Kristanti ${ }^{1 *}$, M. Tanjung ${ }^{1}$ and O. P. Rahayu ${ }^{1}$ \\ ${ }^{1}$ Laboratory of Organic Chemistry, Department of Chemistry, Faculty of Science and \\ Technology, Universitas Airlangga, Surabaya 60115, Indonesia
}

\begin{abstract}
THIS study reported the isolation of 7-hydroxy-5,3',4'-trimethoxyflavone (1) from stem bark of Aquilaria microcarpa, a species belonging to Thymelaeaceae family. This report is our continuation study about this plant. Previously, we reported the presence of 5,3',4'-trihydroxy-7-methoxyflavon and 6-hydroxy-2-(2-phenylethyl) chromon The chemical structure of compound (1) has been elucidated based on spectroscopy method including FTIR, NMR and HRESI-MS analysis.
\end{abstract}

Keywords : 7-hydroxy-5,3',4'-trimethoxyflavone; flavonoid, Aquilaria microcarpa; Thymelaeaceae

\section{Introduction}

The Thymelaeaceae is a family of dicotyledonous plants mainly found in the tropics and subtropics. They are mostly trees and shrubs, but include also a few vines and herbaceous plants. It is recognized that Thymelaeaceae composed by 45 genus [1]. Among these 45 genera, Aquilaria, Daphne, Gnidia dan Phaleria are the most widely studied and reported genus. The genus of Aquilaria is distributed widely in Asia. A. sinensis, $A$. malaccensis, A. hirta, A. crassna, and A. agallocha are the widely studied species of Aquilaria, but some species have not been investigated, such as $A$. acuminata, $A$. baillonii, $A$. citrinicarpa, $A$. filaria, A. grandiflora, A. microcarpa etc. Certain trees of Aquilaria produce the fragrant resinous wood, called agarwood, eaglewood, gaharu, kanankoh, jinkoh, chen xiang or tram in different region [2,3]. Other people also call it aloeswood or agalloch [3]. This agarwood could be used as incense which has been widely present in the religious ceremony of traditional culture $[4,5]$ and used also as traditional medicine [2,6-10]. Due to the odor produced, agarwood now is a material for perfume and aromatherapy, in addition to all the other benefits since antiquity. The Aquilaria is of prime importance owing to its richness in a variety of different classes of natural product, especially sesquiterpenes and chromones. Other classes of compounds are flavonoid, benzophenone, diterpenoid, triterpenoid and lignan.
In continuation of our research about the secondary metabolites contained in $A$. microcarpa, we report here the isolation and structural elucidation of a flavonoid, 7-hydroxy5,3',4'-trimethoxyflavone (1) (Figure 1) from the stem bark of this plant. Previously, we reported the presence of two phenolic compounds, namely 5,3 ',4'-trihydroxy-7-methoxyflavon or known as 3'-hydroxy genkwanin and 6-hydroxy-2-(2phenylethyl) chromon from the same plant [11]. Compound (1) has only ever been reported once in the plant by some Chinese researchers. It was first isolated and identified from the leaf of Murraya panaculata, but the spectroscopy data was not available [12]. There is not any publication reported about the presence of this compound in Aauilaria, even in Thvmelaeaceae.<smiles>COc1ccc(-c2cc(=O)c3c(OC)cc(O)cc3o2)cc1OC</smiles>

Fig. 1. Structure of 7-hydroxy-5,3',4'trimethoxyflavone (1)

\section{Experimental}

\section{General experimental}

The UV spectrum was measured with Shimadzu series 1800 spectrophotometer (Kyoto, Japan). The FTIR spectrum was recorded in $\mathrm{KBr}$ 
powder with the Diffuse Reflectance Method on spectrophotometer IRTracer 100 (Shimadzu, Kyoto, Japan). NMR Spectra $\left({ }^{1} \mathrm{H}, \mathrm{APT}, \mathrm{HMBC}\right.$ and HMQC) were recorded on JEOL 400 ECA spectrometer (JEOL, Tokyo, Japan) using $\mathrm{CDCl}_{3}$ as a solvent and internal standard. The mass spectrum was recorded by HRESI-MS (Waters LCT Premier XE, Waters Corp. Milford, MA, USA).

\section{Plant Material}

Samples of stem bark of $A$. microcarpa were collected in October 2015 from Conservation forest Bukit Bangkirai, Samboja, Samarinda, East Kalimantan, Indonesia and the voucher specimen (UA-TAm011015) was deposited at the Herbarium of Universitas Airlangga. The stem bark was cleaned, air dried under the shade, cut into small pieces and milled.

\section{Extraction and Isolation}

The dried stem barks of $A$. microcarpa $(1.69 \mathrm{~kg})$ were macerated with n-hexane at room temperature for $2 \times 24$ hours followed by maceration using methanol for $3 \times 24$ hours. The methanol extract was evaporated under reduced pressure to give a crude methanol extract (120 g). Into this extract was then added water and partitioned with ethyl acetate. The ethyl acetate extract obtained was evaporated under reduced pressure to give a crude ethyl acetate extract (10.8 g). Ethyl acetate extract was separated by flash cromatography on silica gel using the mixture of n-hexane-ethyl acetate as eluent. Elution was done by increasing the polarity gradually by increasing the amount of ethyl acetate to give five major fractions A-E. TLC on fraction E (250 $\mathrm{mg}$ ) using eluent chloroform showed a potential spot. Purification of this fraction using flash chromatography twice with eluent n-hexane-ethyl acetate and n-hexane-chloroform respectively, yielded compound (1) (20 mg).

\section{Results and Discussion}

Compound (1) was obtained as a yellow solid (mp $172-174^{\circ} \mathrm{C}$ ) after passing through a series of isolation steps, including extraction followed by separation and purification using chromatographic techniques. The molecular formula is $\mathrm{C}_{18} \mathrm{H}_{17} \mathrm{O}_{6}$, whereas that of the protonated molecule $[\mathrm{M}+\mathrm{H}]^{+}$ is $\mathrm{C}_{18} \mathrm{H}_{18} \mathrm{O}_{6}$ at $\mathrm{m} / z 329.1024$ (calcd. 329.1025) by the HR-ESI-MS. The UV spectrum showed two absorption bands, benzoyl and cinamoyl moiety, characteristic of flavonoid skeleton at $\lambda_{\text {maks }} 269$ (4.19) and 340 (4.24) nm. The IR spectrum showed absorption bands at $v_{\max } 3280$, 3093, 2924, 1618, 1587, 1517, 1261, $831 \mathrm{~cm}^{-1}$ indicating the presence of a hydoxyl, aromatic group, conjugated carbonyl and methoxy group. ${ }^{1} \mathrm{H}-\mathrm{NMR}$ spectrum showed a singlet signal at $\delta_{\mathrm{H}}$ $6.60 \mathrm{ppm}$ which was a characteristic of flavon group. There were also five signals of aromatic protons which appeared at $\delta_{\mathrm{H}} 7.53 \mathrm{ppm}\left(\mathrm{H}_{6}, d d, J\right.$ $=8.6$ and $2.1 \mathrm{~Hz}) ; 7.34 \mathrm{ppm}\left(\mathrm{H}_{2}, d, J=2.1 \mathrm{~Hz}\right)$; $6.98 \mathrm{ppm}\left(\mathrm{H}_{5}, d, J=8.6 \mathrm{~Hz}\right)$. These three signals described the existence of ABX system. Two other signals appeared as doublet at $\delta_{H} 6.50$ and $6.38 \mathrm{ppm}$. Both of signals indicated that these two protons were in meta position. In addition, it was also observed the presence of three singlet signals of methoxy group at $\delta_{\mathrm{H}} 3.99 ; 3.97$ and $3.89 \mathrm{ppm}$ (Table 1). ${ }^{13} \mathrm{C}$-NMR ATP spectrum showed 18 completely separated signals, which is consistent with the structure of substituted flavone. Through the spectrum it can be seen that this compound was composed by six methins $(\mathrm{CH})\left(\delta_{\mathrm{C}} 120.2\right.$; $111.2 ; 108.8 ; 104.8 ; 98.2$ and $92.8 \mathrm{ppm})$, three methoxy $\left(\mathrm{OCH}_{3}\right)\left(\delta_{\mathrm{C}} 56.2 ; 56.1\right.$; and $\left.55.9 \mathrm{ppm}\right)$, and 9 quarternary carbon $\left(\delta_{\mathrm{C}} 182.4 ; 165.5 ; 164.7\right.$; $164.1 ; 162.3 ; 152.2 ; 149.3 ; 123.8$ dan 105.6 ppm) (Table 1).

The HMQC spectrum gave the information about the correlation between directly-bonded $\mathrm{H}$ on $\mathrm{C}$, so through this spectrum we obtained the information about which proton is attached to which carbon. In the HMBC spectrum, it was observed the presence of long range correlations between the proton signal aromatic $\mathrm{H}-8\left(\delta_{\mathrm{H}} 6.98\right)$ with three quarternary carbon signals at $\delta_{\mathrm{C}} 164.7$ (C-7), 162.3 (C-8a), 105.6 (C-4a) and one methin at $\delta_{C} 98.2(\mathrm{C}-6)$. The appearance another long range correlations between the proton signal aromatic H-6 $\left(\delta_{\mathrm{H}} 6.38\right)$ with three quarternary carbon signals at $\delta_{\mathrm{C}} 165.5(\mathrm{C}-5), 164.7$ (C-7), $105.6(\mathrm{C}-4 \mathrm{a})$ and one methin at $\delta_{\mathrm{C}} 92.8(\mathrm{C}-8)$ placed certainly the methoxy at the $\mathrm{C}-5$ and not at $\mathrm{C}-7$ in the ring A. This argument was supported by the existence of the correlation of three methoxys with three oxyaryl carbons, which are $-\mathrm{OCH}_{3}\left(\delta_{\mathrm{H}}\right.$ $3.99)$ with an oxyaryl carbon $\left(\delta_{\mathrm{C}} 152.2 ; \mathrm{C}^{\prime} 4^{\prime}\right)$; $-\mathrm{OCH}_{3}\left(\delta_{\mathrm{H}} 3.97\right)$ with an oxyaryl carbon $\left(\delta_{\mathrm{C}} 149.3\right.$; $\left.\mathrm{C}-3^{\prime}\right)$ and $-\mathrm{OCH}_{3}\left(\delta_{\mathrm{H}} 3.89\right)$ with an oxyaryl carbon (at $\delta_{\mathrm{C}} 165.5$; C-5). All of data obtained from NMR are presented in Table 1. Correlations observed in HMBC spectrum are described in Fig. 2. Therefore, compound (1) was elucidated as 7-hydroxy-5, 3', 4'-trimethoxyflavone. 


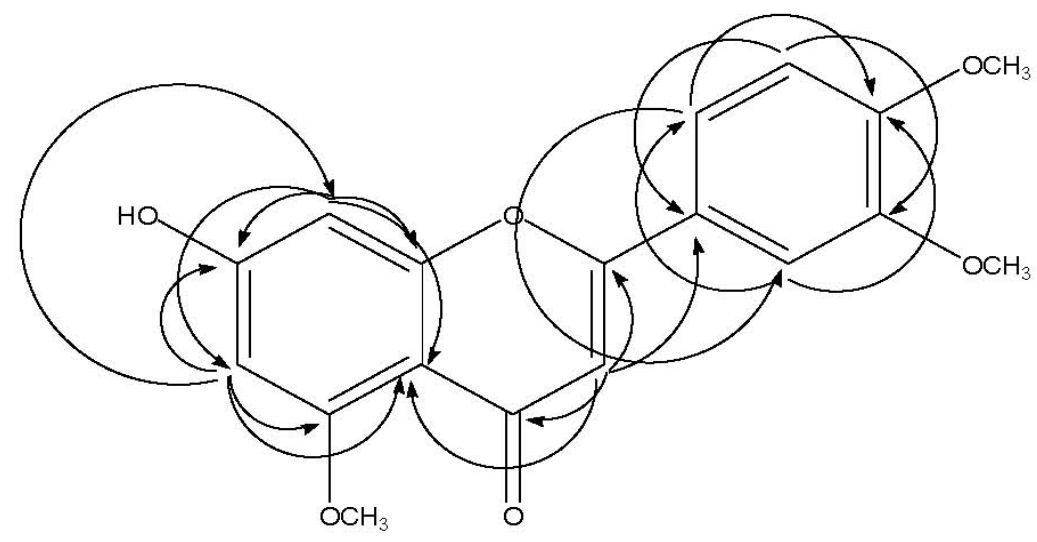

Fig. 2. HMBC correlations of compound (1)

TABLE $1 .{ }^{1} \mathrm{H},{ }^{13} \mathrm{C}$ and $\mathrm{HMBC}$ NMR data of compound (1) in $\mathrm{CDCl}_{3}(\delta$ in ppm)

\begin{tabular}{|c|c|c|c|}
\hline No. Atom & $\delta_{\mathrm{H}}(\mathrm{mult}, J \mathrm{~Hz})$ & $\boldsymbol{\delta}_{\mathrm{C}}$ & HMBC \\
\hline 2 & - & 164.1 & \\
\hline 3 & $6.60(\mathrm{~s})$ & 104.8 & $\mathrm{C}-2, \mathrm{C}-4, \mathrm{C}-1^{\prime}, \mathrm{C}-4 \mathrm{a}$ \\
\hline 4 & - & 182.4 & \\
\hline $4 a$ & - & 105.6 & \\
\hline 5 & - & 165.5 & \\
\hline 6 & $6.38(\mathrm{~d}, J=2.2 \mathrm{~Hz})$ & 98.2 & C-4a, C-5, C-7, C-8 \\
\hline 7 & - & 164.7 & \\
\hline 8 & $6.50(\mathrm{~d}, J=2.2 \mathrm{~Hz})$ & 92.8 & C-4a, C- $6, C 7, C-8 a$ \\
\hline $8 \mathrm{a}$ & - & 162.3 & \\
\hline 1 ' & - & 123.8 & \\
\hline 2 ' & $7.34(\mathrm{~d}, J=2.1 \mathrm{~Hz})$ & 108.8 & C-4, C-6' \\
\hline 3 ' & - & 149.3 & \\
\hline 4 & - & 152.2 & \\
\hline 5 , & $6.98(\mathrm{~d}, J=8.6 \mathrm{~Hz})$ & 111.2 & C-1', C-3' \\
\hline 6 ' & $\begin{array}{l}7.53(\mathrm{dd}, J=8.6 \& 2.1 \\
\mathrm{Hz})\end{array}$ & 120.2 & C-2', C-4' \\
\hline $5-\mathrm{OCH}_{3}$ & $3.89(\mathrm{~s})$ & 55.9 & $\mathrm{C}-5$ \\
\hline $3^{\prime}-\mathrm{OCH}_{3}$ & $3.97(\mathrm{~s})$ & 56.1 & C-3' \\
\hline $4^{\prime}-\mathrm{OCH}_{3}^{3}$ & $3.99(\mathrm{~s})$ & 56.2 & C-4' \\
\hline
\end{tabular}

The spectrum data was compared with similar compound, namely 5,7,3',4'-tetramethoxyflavone which was isolated and identified from Kaempferia parviflora, reported by Sutthanut [13].

\section{Conclusion}

A flavonoid namely 7-hydroxy-5,3',4'trimethoxyflavone was successfully isolated and identified from stem bark of Aquilaria microcarpa, a species belonging to Thymelaeaceae. This is the first time that this compound reported found in Aquilaria, even in Thymelaeaceae.

\section{Acknowledgements}

This research was supported by Ministry of Research, Technology and Higher Education, Republik Indonesia (Penelitian Unggulan Perguruan Tinggi, 2016).

Egypt. J. Chem. 61, No.2 (2018) 


\section{References}

1. Herber, B.E., "The Families and Genera of Vascular Plants", ed. K. Kubitzki and C. Bayer, Vol. 5, Springer-Verlag, Berlin (2003).

2. Li, W., Cai, C.H., Dong, W.H., Guo, Z.K., Wang, H., Mei, W.L. and Dai, H.F., 2-(2-phenylethyl) chromone derivatives from Chinese agarwood induced by artificial holing. Fitoterapia, 98, 117 (2014).

3. Ueda, J., Imamura, L.. Tezuka, Y., Tran, Q.L., Tsuda, M. and Kadota, S., New sesuiterpene from Vietnamese agarwood and its induction effect on brain-derived neurotrophic factor mRNA expression in vitro. Bioorg. Med. Chem, 14, 3571 (2006).

4. Alkhathlan, H.Z., Al-Hazimi, H.M., Al-Dhalaan, F.S. and Mousa, A.A., Three 2-(2-phenylethyl) chromones and two terpenes from agarwood. Nat Prod Res, 19 (4), 367 (2005).

5. Yang, D.L., Wang, H., Guo, Z.K., Dong, W.H., Mei, W.L. and Dai, H.F., A new 2-(2-phenylethyl) chromone derivative in Chinese agarwood "QiNan" from Aquilaria sinensis. J Asian Nat Prod Res, 16 (7), 770 (2014).

6. Bhuiyan, M.N.I., Begum, J. and Bhuiyan, M.N.H., Analysis of essential oil of eaglewood tree (Aquilaria agallocha Roxb.) by gas chromatography mass spectrometry. Bangladesh J. Pharmacol., 4, 24 (2009).

7. Kim, Y.C., Lee, E.H., Lee, Y.M., Kim, H.K., Song, B.K., Lee, E.J. and Kim, H.M., Effect of the aqueous extract of Aquilaria agallocha stems on the immediate hypersensitivity reactions. $J$ Ethnopharmacol, 58, 31 (1997).

8. Nakanishi, T., Inada, A., Nishi, M., Yamagata, E. and Yoneda, K., A new and a known derivatives of 2-(2-phenylethyl) chromone from a kind of agarwood ("kanankoh" in Japanese) originating from Aquilaria agallocha. J. Nat. Prod., 49(6), 1106 (1986).

9. Yagura, T., Iro, M., Kiuchi, F., Honda G. and Shimada, Y., Four new 2-(2-phenylethyl) chromone derivatives from withered wood of Aquilaria sinensis. Chem Pharm Bull, 51(5), 560 (2003).

10. Zhou, M., Wang, H., Suolangjiba, Kou, J. and $\mathrm{Yu}, \mathrm{B}$, Antinociceptive and anti-inflammatory activities of Aquilaria sinensis (Lour.) Gilg. leaves extract. J Ethnopharmacol, 117, 345 (2008).

11. Kristanti, A.N., Tanjung, M. and Rahayu, O.P., Phenolic compounds from Aquilaria microcarpa stem bark. J. Chem. Technol. Metall., 52, 1111 (2017).

12. Shan, J., Wang, X.Z., Ma, Y.D., Yang, R.J., Li, X.W. and Jin, Y.R., Studies on flavonoids from leaves of Murraya panaculata L. Zhongguo Yaoxue Zazhi, 45, 1910 (2010).

13. Sutthanut, K., Sripanidkulchai, B., Yenjai, C. and Jay, M., Simultaneous identification and quantitation of 11 flavonoid constituents in Kaempferia parviflora by gas chromatography. J. Chromatogr. A, 1143, 227 (2007).

(Received 28/11/2017 accepted 12/2/2018) 